\title{
TRAIL Receptor Agonist ABBV-621
}

National Cancer Institute

\section{Source}

National Cancer Institute. TRAIL Receptor Agonist ABBV-621. NCI Thesaurus. Code C146854.

A fusion protein composed of a tumor necrosis factor (TNF)-related apoptosis-inducing lig and (TRAIL) receptor agonist consisting of six receptor binding domains (RBDs) of TRAIL fused to the Fc-domain of a human immunoglobulin G1 (IgG1) antibody, with potential pro-apoptotic and antineoplastic activities. Upon administration of TRAIL receptor agonist ABBV-621, this fusion protein binds to TRAIL-receptors, pro-apoptotic death receptors (DRs) TRAIL-R1 (death receptor 4; DR4) and TRAIL-R2 (death receptor 5; DR5), expressed on tumor cells, thereby inducing tumor cell apoptosis. ABBV-621 is designed to maximize receptor clustering for optimal efficacy. TRAIL, a member of the TNF superfamily of cytokines, plays a key role in the induction of apoptosis through TRAIL-mediated death receptor pathways. 